\title{
Pengembangan Sistem Pengelolaan dan Pemantauan Proyek dengan Metode Agile Pola Scrum
}

\author{
http://dx.doi.org/10.28932/jutisi.v6i2.2592
}

\author{
Adhe Rama Febrianto ${ }^{\bowtie}$, Anita Wulansari ${ }^{* 2}$, Latipah ${ }^{\# 3}$ \\ \#Jurusan Sistem Informasi, Universitas Narotama \\ Jl. Arief Rachman Hakim 51, Sukolilo, Kota Surabaya \\ 'adheramaf7@gmail.com \\ 3latifah.rifanienarotama.ac.id \\ *Jurusan Sistem Informasi, Universitas Narotama \\ Jl. Arief Rachman Hakim 51, Sukolilo, Kota Surabaya \\ zanita.wsari@narotama.ac.id
}

\begin{abstract}
Vsualproject is a business unit of Visi Prima Group which is located in Gresik, a business engaged in software development. In working on the project, the Vsualproject is required to complete the task on time as well as under the customers' requirement. Current management processes were still done manually which consist of recording in the Whatsapp application chat group. In a software development project, it is also necessary to develop the desired interests to find out whether it is under the organization' demands and needs. Keeping notes in the WhatsApp chat group makes notes frequently disappeared and the search process was more complicated about who requests the development process. The purpose of this research is to develop a system that can help Vsualproject to manage projects and provide services to their customers with the project monitoring feature. The system was developed using the Scrum pattern Agile development method which was carried out during the four-cycle sprints. The results of the development of the system were tested by the Black Box Testing method to ensure that the system meets the user's requirements. The result of this study produced a project management system that can be used by internal users of Vsualproject management projects includes managing the stages, payment, and project's works. The system can also be used by customers to monitor projects through a web profile without asking for special access rights.
\end{abstract}

Keywords- Project Management; Project Monitoring; Agile; Scrum.

\section{Pendahuluan}

Software house merupakan sebuah bisnis yang bergerak di bidang software development yang produk utamanya adalah mengembangkan dan menyediakan software [1]. Vsualproject merupakan cabang usaha dari Visi Prima Group yang bergerak di bidang software house. Vsualproject berlokasi di Kabupaten Gresik. Proses pengelolaan dan pencatatan perkembangan proyek yang dilakukan masih secara manual yaitu berupa pencatatan di grup obrolan aplikasi WhatsApp. Selain pengelolaan dari sisi internal, dalam suatu pengembangan perangkat lunak juga diperlukan adanya pemantauan perkembangan dari pelanggan untuk mengetahui apakah hasilnya sesuai dengan permintaan dan kebutuhan. Dengan disimpannya catatan di grup obrolan aplikasi WhatsApp, maka membuat proses pencarian catatan proyek menjadi kurang cepat dan sering hilangnya catatan.

Dalam pengembangan sebuah sistem sulit untuk memprediksi hal-hal yang akan terjadi selama proses pengembangan salah satunya yaitu adanya perubahan atau penambahan kebutuhan sistem. Kegagalan dalam adaptasi menjadi salah satu penyebab kegagalan pengembangan sistem, maka diperlukan sebuah metode pengembangan yang tanggap dalam menangani perubahan sistem. Salah satu metode yang tanggap dalam menangani perubahan adalah metode pengembangan Agile dengan pola Scrum. Metode pengembangan Agile dengan pola Scrum selain mempunyai prinsip tanggap dalam menangani perubahan, metodi ini juga menekankan iterasi dalam proses pengembangan dan pengiriman produk kepada pemangku kepentingan [2].

Berdasarkan latar belakang tersebut, tujuan dari penelitian ini yaitu mengembangkan sistem yang dapat membantu proses pengelolaan proyek meliputi proses pengelolaan tahapan, pembayaran dan pekerjaan proyek. Selain itu, juga akan dikembangkan website company profile yang bertujuan untuk memudahkan pelanggan dalam melakukan pemantauan perkembangan proyek yang dipesan. Pengembangan sistem dilakukan dengan mengadaptasi metode pengembangan Agile dengan pola Scrum untuk dapat menangani apabila terjadi perubahan pada proses pengembangan.

Manfaat yang dapat diambil dari implementasi sistem ini yaitu memberikan kemudahan kepada Visi Prima Group 
khususnya Vsualproject dalam pengelolaan proyek meliputi pencatatan tahapan proyek, pembayaran proyek, dan pekerjaan proyek. Selain itu, sistem ini dapat memberikan nilai layanan lebih kepada pelanggan Vsualproject dengan adanya fitur pemantauan perkembangan proyek yang dapat dilakukan secara langsung oleh pelanggannya melalui halaman pencarian proyek.

Batasan masalah pada penelitian ini yaitu: Pertama, pengembangan sistem berfokus pada pengelolaan proyek sisi administrator dan pemantauan perkembangan sisi pelanggan dari Visi Prima Group. Kedua, metode dalam mengembangkan sistem dengan menerapkan metode pengembangan Agile dengan pola pendekatan Scrum. Ketiga, Perancangan sistem menggunakan Unified Modelling Language dan uji coba sistem menggunakan Black Box Testing.

\section{TinjauAn Pustaka}

\section{A. Penelitian Terdahulu}

Dalam penelitian ini dipaparkan delapan penelitian terdahulu yang relevan dengan penelitian yang akan dilakukan. Penelitian pertama berjudul "Pengembangan Sistem Aplikasi Manajemen Proyek Berbasis Web (Studi Kasus: PT. Swadaya Graha)" yang ditulis oleh Ardian Riftha Dhuha, Fajar Pradana, dan Bayu Priyambadha. Penelitian tersebut menjelaskan pemanfaatan teknologi informasi yang dikombinasikan dengan metode Critical Path Method. Penelitian ini menghasilkan sistem yang dapat membantu perusahaan dalam melakukan perencanaan, meminimalisir ketidaksesuaian antara rencana dan realisasi, optimalisasi perhitungan biaya, dan memudahkan proses dokumentasi laporan [3]. Perbedaan penelitian tersebut dengan penelitian yang akan dilakukan yaitu pada metode yang digunakan dalam sistem yang dibuat. Pada penelitian yang akan dilakukan tidak menggunakan metode untuk sistem yang akan dikembangkan.

Penelitian kedua berjudul "Rancang Bangun Sistem Informasi Kolaboratif Berbasis Web Untuk Manajemen Proyek Teknologi Informasi" oleh Dewi Paramita. Penelitian kedua ini menjelaskan pengembangan sistem informasi berbasis web dengan fitur kolaboratif yang membuat interaksi antara pemilik dan pengguna menjadi lebih mudah dan fleksibel. Penelitian kedua ini menghasilkan sistem untuk membantu perusahaan dalam memilih konsultan, mengelola, serta mengawasi proyek yang berlangsung [4]. Keterkaitan dengan penelitian yang akan dilakukan yaitu terdapatnya fitur untuk klien atau pelanggan melakukan pemantauan perkembangan proyek.

Penelitian ketiga yaitu penelitian oleh Kresna Ramanda (2017) yang berjudul "Sistem Informasi Manajemen Proyek Berbasis Web". Penelitian ketiga ini menjelaskan manajemen sangat membutuhkan bantuan secara sistem untuk manajemen proyek karena proses pengerjaan data masih dikerjakan secara manual. Sehingga dengan adanya sistem, manajemen dapat mengelola data dan dapat melihat perkembangan proyek yang kemudian dijadikan sebagai acuan dalam pengambilan keputusan. Proses pengembangan sistem menggunakan metode Waterfall. Penelitian ketiga ini menghasilkan sistem yang dapat membantu perusahaan dalam melakukan pengawasan terhadap proyeknya, serta dapat digunakan sebagai acuan dalam pengambilan keputusan berdasarkan data yang ada pada sistem [5]. Perbedaan dengan penelitian yang akan dilakukan yaitu pada metode pengembangan yang digunakan untuk mengembangkan sistem, pada penelitian yang akan dilakukan menggunakan metode Agile pola Scrum.

Penelitian keempat yaitu penelitian oleh Tata Sumitra dan M. Arief Sutina yang berjudul "Sistem Informasi Manajemen Proyek pada PT. Sempana Pratama Menggunakan PHP \& My SQL". Penelitian ketiga ini menjelaskan tentang pengembangan sistem informasi manajemen proyek menggunakan metode Prototyping. Penelitian keempat ini menghasilkan sistem yang dapat membantu proses manajamen proyek perusahaan menjadi lebih baik sehingga dapat meningkatkan kualitas dan menghasilkan pola kerja yang efektif dan efisien [6]. Perbedaan dengan penelitian yang akan dilakukan yaitu pada metode pengembangan yang digunakan untuk mengembangkan sistem, pada penelitian yang akan dilakukan menggunakan metode Agile pola Scrum.

Penelitian kelima yaitu berjudul "Perancangan Aplikasi Berbasis Android untuk Manajemen Proyek Reparasi Kapal" oleh Marlen Jenri Hutapea, Triwilaswandio Wuruk Pribadi, dan Imam Baihaqi. Penelitian ini menggunakan metode Mock Up Aplikasi dalam proses pengembangannya. Penelitian ini menjelaskan manajemen proyek sebuah galangan dalam mereparasi kapal sangat dibutuhkan agar sebuah proyek berjalan sesuai rencana yang telah dibuat. Manajemen proyek akan lebih mudah dilakukan dengan adanya sistem yang mendukung agar informasi dapat tersampaikan dengan cepat. Penelitian ini menghasilkan aplikasi berbasis android yang dapat membantu galangan khususnya Project Manager dalam perencanaan, penjadwalan, dan pengawasan terhadap pengerjaan proyek [7]. Perbedaan dengan penelitian yang akan dilakukan yaitu pada metode pengembangan yang digunakan untuk mengembangkan sistem, pada penelitian yang akan dilakukan menggunakan metode Agile pola Scrum, dan platform sistem yang digunakan pada penelitian ketiga ini adalah platform mobile, sedangkan pada penelitian yang akan dilakukan menggunakan platform web.

Penelitian keenam berjudul "Agile Project Management pada Pengembangan E-Musrenbang Kelurahan Benoa Bali” oleh Kadek Cahya Dewi, Putu Indah Ciptayani, dan I Wayan Rizky Wijaya. Pada penelitian tersebut menjelaskan penerapan manajemen proyek berbasis Agile. Penelitian tersebut menghasilkan sistem yang yang dapat membantu perencanaan pembangunan tingkat Kelurahan Benoa sehingga dapat menghasilkan laporan yang sesuai dengan musrenbang tingkat kecamatan. Dari penelitian tersebut didapatkan data waktu pengembangan dengan Agile yaitu 
selama delapan minggu yang terbagi menjadi empat sprint [8]. Keterkaitan dengan penelitian yang akan dilakukan yaitu pada metode yang digunakan sama-sama menggunakan metode Agile, sehingga penelitian tersebut dapat dijadikan acuan dalam penelitian yang akan dilakukan.

Penelitian ketujuh berjudul "Scrum Method Implementation in a Software Development Project Management" oleh Putu Adi Guna Permana. Pada penelitian tersebut menjelaskan bahwa dalam implementasi metode Scrum, selama proses pengembangan dapat segera diketahui kualitas dan resiko secara cepat, perubahan alur bisnis dan feedback pelanggan dapat diketahui di sprint terakhir, dan proses deployment dapat dilakukan di setiap product backlog [9]. Keterkaitan dengan penelitian yang akan dilakukan yaitu pada penerapan metode Scrum, sehingga penelitian tersebut dapat dijadikan acuan penelitian yang akan dilakukan.

Penelitian kedelapan yaitu penelitian oleh Ikhwansyah Kurniawan dan Ramadhan Rakhmat Sani yang berjudul "Pemodelan SCRUM dalam Pengembangan Sistem Informasi Kesehatan pada Klinik Ar-Rokhim Sragen Kabupaten Sragen". Pada penelitian tersebut menjelaskan bahwa pada Klinik Ar-Rokhim dalama proses bisnisnya belum memaksimalkan aplikasi sistem yang ada, sehingga perlu dikembangkan sistem yang dapat membuat proses bisnis pada klinik menjadi efektif dan efisien. Penelitian tersebut bertujuan menghasilkan sistem informasi dengan cepat dalam menanggapi perubahan dan sesuai dengan target yang diharapkan, sehingga penelitian tersebut memanfaatkan Scrum untuk mendukung proses pengembangan sistem [10]. Keterkaitan dengan penelitian yang akan dilakukan yaitu pada penerapan metode Scrum, sehingga penelitian tersebut dapat dijadikan acuan penelitian yang akan dilakukan.

\section{B. Manajemen Proyek Perangkat Lunak}

Kegiatan manajemen proyek perangkat lunak dimulai sebelum berbagai kegiatan teknis dimulai dan berlanjut sepanjang proses modeling, construction, dan deployment software [11]. Terdapat "Four P's" elemen yang mempunyai pengaruh besar terhadap manajemen proyek, yaitu: 1) People, orang-orang harus diatur ke dalam tim yang efektif, dimotivasi untuk melakukan pengembangan perangkat lunak yang berkualitas tinggi, dan terkoordinasi untuk mencapai komunikasi yang efektif; 2) Product, kebutuhan perangkat lunak harus disampaikan dari pelanggan ke pengembang, kebutuhan perangkat lunak didekomposisi sesuai dengan bagiannya, dan diposisikan untuk kemudian dikerjakan oleh tim pengembang; 3) Process, harus disesuaikan dengan people dan product. Pemilihan kerangka kerja, penereapan paradigma pengembangan perangkat lunak, dan sekumpulan tugas kerja untuk menyelesaikan suatu pekerjaan; 4) Project, harus diatur sedemikian rupa sehingga tim pengembang dapat berhasil menyelesaikan proyek [11].
Elemen penting dalam semua proyek perangkat lunak adalah elemen people. Software engineer dapat diatur dalam sejumlah struktur tim yang berbeda, mulai dari hierarki kontrol tradisional hingga tim "paradigma terbuka". Berbagai teknik koordinasi dan komunikasi dapat diterapkan untuk mendukung pekerjaan tim. Secara umum, ulasan teknis dan komunikasi orang-ke-orang informal memiliki nilai paling tinggi bagi para praktisi [11].

\section{Metode Pengembangan Agile dengan Pola Pendekatan Scrum}

Metode pengembangan Agile secara umum bergantung pada pendekatan tambahan untuk spesifikasi, pengembangan, dan pengiriman perangkat lunak kepada pelanggan. Metode ini paling cocok digunakan untuk pengembangan aplikasi yang spesifikasi sistemnya berubah dengan cepat selama proses pengembangan [2]. Ada lima prinsip dari metode pengembangan Agile yaitu customer involvement, incremental delivery, people not process, embrace change, dan maintain simplicity. Customer envolvement berarti pelanggan harus terlibat selama proses pengembangan perangkat lunak. Peran dari pelanggan di sini yaitu sebagai sumber penyedia persyaratan maupun spesifikasi baru dalam sistem dan untuk mengevaluasi sistem yang sudah dikembangkan. Incremental delivery berarti pengembangan perangkat lunak dilakukan secara bertahap dengan pelanggan menentukan persyaratan untuk dimasukkan dalam setiap kenaikan. Pada prinsip people not process, setiap anggota tim pengembang dibiarkan untuk mengelola pekerjaan mereka secara mandiri tanpa proses preskriptif atau memberi arahan secara berlebihan atau biasa disebut self organized. Prinsip embrace change berarti perubahan persyaratan maupun spesifikasi dan desain sistem yang dapat mengakomodasi perubahan. Dan prinsip maintain simplicity dapat diartikan sebagai fokus pada kesederhanaan dari perangkat lunak yang dikembangkan dan dalam proses pengembangan. Jika memungkinkan, bekerja secara aktif untuk mengurangi kompleksitas dari sistem [2].

Pola pendekatan Scrum menerapkan metode Agile secara umum tetapi berfokus pada pengelolaan pengembangan berulang daripada pendekatan teknis secara spesifik untuk rekayasa perangkat lunak dengan metode Agile. Terdapat tiga fase dalam Scrum seperti yang ditunjukkan pada Gambar 1.

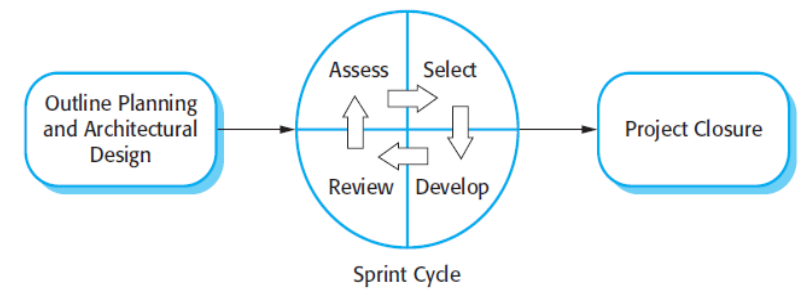

Gambar 1. Proses Scrum [2] 
Fase pertama adalah fase perencanaan garis besar yang digunakan untuk menetapkan tujuan umum untuk proyek dan merancang arsitektur perangkat lunak. Kemudian fase kedua adalah sprint cycle atau siklus sprint, dimana setiap siklus mengembangkan penambahan dari sistem. Di fase sprint ini dilakukan perencanaan mana pekerjaan yang akan dilakukan, dinilai, fitur dipilih untuk pengembangan, dan perangkat lunak diimplementasikan. Di akhir sprint, fungsionalitas yang selesai dikirim ke pemangku kepentingan. Fase ketiga atau terakhir yaitu fase penutupan proyek dengan melengkapi dokumentasi yang diperlukan seperti kerangka bantuan sistem dan buku pedoman pengguna, serta menilai pelajaran yang dipetik dari proyek yang sudah dikerjakan [2].

\section{Unified Modeling Language (UML) Versi 2.5}

Unified Modeling Language (UML) digunakan untuk mendokumentasikan, menspesifikasikan, dan membangun perangkat lunak dengan bahasa spesifikasi standar. UML sering digunakan sebagai metodololgi pengembangan sistem berorientasi obyek dan juga sebagai alat untuk mendukung pengembangan system. Jenis-jenis diagram yang digunakan dalam perancangan berorientasi obyek yaitu:

1) Use Case Diagram: Use case digunakan untuk mengetahui fungsi apa saja yang ada di dalam sistem dan siapa saja yang berhak menggunakan fungsi-fungsi tersebut. Simbol-simbol yang terdapat pada Use Case Diagram yaitu use case, actor, dan asosiasi antara use case dan actor. Simbol use case menggambarkan fungsionalitas yang disediakan sistem sebagai unit yang bertukar pesan antar unit dengan aktor dan dinyatakan dengan kata kerja. Simbol actor menggambarkan abstraksi dari orang atau sistem lain yang mengaktifkan fungsi dari target sistem. Asosiasi antara actor dan use case digambarkan dengan garis tanpa panah yang mengindikasikan siapa yang meminta interaksi secara langsung [12].

2) Activity Diagram (Diagram Aktivitas): Diagram aktivitas digunakan untuk menggambarkan aliran kerja atau aktivitas dari sebuah sistem atau proses bisnis. Simbolsimbol yang digunakan dalam diagram aktivitas yaitu start point, end point, decision point, dan swimlane. Start point digunakan sebagai symbol penanda dimulainya alur dari diagram aktivitas. End point digunakan sebagai simbol penanda berakhirnya diagram aktivitas. Simbol activities menggambarkan proses atau kegiatan bisnis yat pada diagram aktivitas. Percabangan digunakan untuk menunjukkan kegiatan yang dilakukan secara paralel atau menggabungkan dua kegiatan menjadi satu. Decision point digunakan sebagai simbol yang menggambarkan pilihan untuk pengambilan keputusan. Swimlane digunakan untuk menggambarkan pembagian stakeholder yang melakukan suatu aktivtitas [12].

3) Sequence Diagram (Diagram Urutan): Diagram urutan digunakan untuk menggambarkan kelakukan obyek pada use case dengan mendeskripsikan waktu hidup obyek dan pesan yang dikirimkan dan diterima antar obyek. Simbol yang digunakan pada sequence diagram yaitu entity class, boundary class, control class, message, dan activation. Entity class berisi kumpulan kelas berupa entitas-entitas yang membentuk gambaran awal sistem dan menjadi landasan untuk menyusun basis data. Boundary class berisi kumpulan kelas yang menjadi interfaces atau interaksi antara satu atau lebih aktor dengan sistem. Control class berisi logika aplikasi yang tidak memiliki tanggung jawab terhadap entitas. Message digunakan sebagai symbol mengirim pesan antar class. Activation digunakan untuk mewakili sebuah eksekusi operasi dari obyek [12].

4) Class Diagram (Diagram Kelas): Class Diagram menggambarkan hubungan antar kelas dan penjelasan detail tiap-tiap kelas yang juga memperlihatkan aturan dan tanggung jawab entitas yang menentukan perilaku sistem. Class diagram juga menunjukkan atribut dan operasi dari sebuah kelas dan batasan yang berhubungan dengan objek yang dikoneksikan. Unsur dari class diagram meliputi kelas, relasi, atribut, operasi, dan visibility. Hubungan antar kelas mempunyai keterangan disebut dengan kardinalitas [12].

\section{Metodologi PENELITIAN}

\section{A. Identifikasi Masalah dan Studi Literatur}

Pada proses identifikasi dilakukan kegiatan observasi dan diskusi informal dengan anggota Visi Prima Group untuk melihat keadaan serta kebutuhan terkait pengembangan sistem. Pada proses ini juga dilakukan penentuan ruang lingkup dan tujuan yang akan dicapai dalam penelitian. Pada proses studi literatur dilakukan pencarian sumber pustaka dari buku maupun jurnal untuk dijadikan referensi pendukung penelitian pengembangan sistem pengelolaan dan pemantauan proyek.

\section{B. Perencanaan Garis Besar}

Pada proses perencanaan garis besar dilakukan dua hal yaitu pembuatan user story dan pembuatan product backlog. Pembuatan user story mengacu pada proses sebelumnya yaitu identifikasi masalah yang sudah ada. User story yang dibuat berisi deskripsi mengenai kebutuhan sistem. Pembuatan product backlog dari user story yang sudah disusun di tahap sebelumnya. Pada setiap product backlog diberi bobot pekerjaan dan tingkat prioritas. Pemberian bobot pekerjaan pada product backlog menggunakan bilangan Fibonacci yaitu 3, 5, 8, dan 13. Bilangan 3 melambangkan bobot pekerjaan kecil, bilangan 5 melambangkan bobot pekerjaan sedang, bilangan 8 melambangkan bobot pekerjaan besar, dan bilangan 13 melambangkan bobot pekerjaan sangat besar. Pemberian tingkat prioritas menggunakan skala Small, Medium, dan Large. Tingkat prioritas menunjukkan tingkat urgent dari setiap pengguna sistem serta dapat sebagai penentuan urutan product backlog yang dikerjakan terlebih dahulu. Peneliti 
menggunakan perangkat lunak Trello untuk membantu penerapan Agile dengan pendekatan Scrum.

\section{Desain Sistem}

Pada tahapan desain sistem ini dilakukan dengan menggunakan pemodelan UML (Unified Modeling Language) versi 2.5. Pemodelan UML yang digunakan adalah Use Case Diagram dan Class Diagram. Pembuatan UML menggunakan perangkat lunak Enterprise Architect.

\section{Siklus Sprint}

Durasi setiap siklus sprint yang dilakukan pada penelitian ini yaitu satu minggu. Siklus sprint dilakukan sampai seluruh product backlog yang dibuat terselesaikan. Pada siklus sprint terdapat lima tahapan yang dilakukan, yaitu:

1) Perencanaan Sprint (Sprint Planning): Tahap perencanaan sprint dilakukan pemilihan product backlog sebagai target yang akan dikerjakan pada sprint terkait yang kemudian dinamakan dengan sprint backlog. Pemilihan product backlog mengacu pada bobot pekerjaan, tingkat prioritas, dan keterkaitan fungsional antar product backlog.

2) Pengembangan Sistem: Pada tahap pengembangan sistem dilakukan pembuatan desain antarmuka menggunakan template web ThemeKit V.2.1 yang berbasiskan framework CSS (Cascading Style Sheet) Bootstrap V4. Pada tahap ini juga dilakukan pengkodean aplikasi menggunakan bahasa PHP (Hypertext Preprocessor) dengan framework Laravel. Database Management System (DBMS) yang digunakan yaitu MariaDB. Pada proses pengembangan peneliti menggunakan perangkat lunak Sublime Text Editor dan database browser SQLYog Ultimate.

3) Testing: Tahap testing sistem menggunakan Black Box Testing untuk menguji fungsional system yang sudah selesai dikembangkan.

4) Sprint Review: Pada tahap sprint review dilakukan demonstrasi hasil dari sprint terkait kepada pemangku kepentingan untuk mendapatkan umpan balik dari apa yang sudah dikerjakan. Apabila terdapat revisi pada hasil yang dikerjakan di sprint terkait maka menjadi product backlog baru dan dikerjakan pada siklus sprint selanjutnya.

5) Deployment: Pada tahap deployment fungsionalitas pada sprint backlog yang selesai dikerjakan diserahkan kepada pemangku kepentingan untuk dapat langsung digunakan. Fungsionalitas sistem yang diserahkan yaitu fungsionalitas yang tidak mengalami revisi pada tahap testing dan sprint review yang melibatkan pemangku kepentingan.

\section{HASIL DAN PEMBAHASAN}

\section{A. User Stories}

User stories berisi nama pengguna sistem dan fitur-fitur yang menjadi kebutuhan sistem. User stories dibuat dengan bahasa pengguna secara umum. Format yang digunakan dalam penulisan user stories dalam penelitian ini yaitu Sebagai seorang <nama pengguna>, dan saya ingin < fitur atau kebutuhan sistem $>$. Dalam sistem yang dibuat terdapat tiga pengguna utama yaitu: administrator, PIC proyek, dan pelanggan. Berikut adalah user stories dari setiap pengguna sistem.

1) User Stories Administrator: Daftar user stories dari administrator yaitu sebagai berikut.

- Sebagai seorang Administrator, dan saya ingin mengelola kelompok jenis proyek. Contoh: Website, Desktop, Mobile.

- Sebagai seorang Administrator, dan saya ingin mengelola kelompok kelajuan atau tahapan dari proyek secara global. Contoh: Tahap Requirement, Tahap Pembayaran, Tahap Pengerjaan.

- Sebagai seorang Administrator, dan saya ingin mengelola data PIC proyek berupa menambah, mengubah, dan menghapus.

- Sebagai seorang Administrator, dan saya ingin mengelola hak akses user yang dapat masuk ke aplikasi.

- Sebagai seorang Administrator, dan saya ingin mencatat proyek yang masuk dan melakukan pencarian dan difilter sesuai jenis dan tahap kelajuan dari proyek.

- Sebagai seorang Administrator, dan saya ingin mencatat data pembayaran proyek.

- Sebagai seorang Administrator, dan saya ingin mencetak atau mengunduh kuitansi pembayaran proyek.

- Sebagai seorang Administrator, dan saya ingin melakukan plotting PIC proyek.

- Sebagai seorang Administrator, dan saya ingin mengelola kelajuan dari proyek yang sudah dicatat.

- Sebagai seorang Administrator, dan saya ingin mengelola daftar pekerjaan proyek.

- Sebagai seorang Administrator, dan saya ingin memperbarui status daftar pekerjaan proyek.

- Sebagai seorang Administrator, dan saya ingin melihat laporan proyek berdasarkan jenis proyek dan jenis tahapan.

- Sebagai seorang Administrator, dan saya ingin melihat laporan jumlah pembayaran dari setiap proyek dan keseluruhan proyek.

2) User Stories PIC Proyek: Daftar user stories dari PIC proyek yaitu sebagai berikut.

- Sebagai seorang PIC proyek, saya ingin melihat proyek yang sudah ditentukan untuk saya.

- Sebagai seorang PIC proyek, saya ingin melihat dan mengelola status kelajuan proyek yang sudah ditentukan untuk saya. 
- Sebagai seorang PIC proyek, saya ingin melihat dan mengelola daftar pekerjaan dari proyek yang sudah ditentukan untuk saya.

3) User Stories Pelanggan: Daftar user stories dari pelanggan yaitu sebagai berikut.

- Sebagai seorang Pelanggan, saya ingin memantau status pengerjaan dari proyek aplikasi yang saya pesan di Visi Prima Group hanya dengan melakukan pencarian berdasarkan nomor proyek pada halaman profil atau halaman tertentu yang disediakan oleh Visi Prima Group tanpa menggunakan hak akses khusus.

- Sebagai seorang Pelanggan, saya ingin memberi feedback pada poin pekerjaan dari proyek aplikasi yang saya pesan di Visi Prima Group. Feedback berupa komentar maupun status selesai dari poin pekerjaan.

- Sebagai seorang Pelanggan, saya ingin memberi penilaian untuk proyek yang aplikasi yang saya pesan di Visi Prima Group ketika proyek sudah berstatus selesai.

\section{B. Product Backlog}

Product backlog berisi fitur yang akan dibuat, bobot pekerjaan, dan tingkat prioritas dari masing-masing fitur. Berdasarkan tahapan pembuatan user stories, maka product backlog ini dibagi menjadi tiga kelompok pengguna sistem, yaitu administrator, PIC proyek, dan pelanggan. Product backlog untuk pengguna administrator dapat dilihat pada Tabel I, untuk PIC proyek dapat dilihat pada Tabel II, dan untuk pelanggan dapat dilihat pada Tabel III.

TABEL I

PRODUCT BACKLOG ADMINISTRATOR

\begin{tabular}{|c|l|c|l|}
\hline No & Fitur & Bobot & Prioritas \\
\hline 1. & Login aplikasi & 5 & Large \\
\hline 2. & Mengelola Data Jenis Proyek & 5 & Large \\
\hline 3. & $\begin{array}{l}\text { Mengelola Data Tahapan } \\
\text { Proyek }\end{array}$ & 5 & Large \\
\hline 4. & Mengelola Data PIC Proyek & 5 & Large \\
\hline 5. & Mengelola Hak Akses User & 5 & Large \\
\hline 6. & Mengelola Data Proyek & 8 & Large \\
\hline 7. & $\begin{array}{l}\text { Mencatat Data Pembayaran } \\
\text { Proyek }\end{array}$ & 3 & Large \\
\hline 8. & $\begin{array}{l}\text { Mencetak Kuitansi Pembayaran } \\
\text { 9. }\end{array}$ & 3 & Medium \\
\hline 10. & $\begin{array}{l}\text { Mengelola Daftar Pekerjaan } \\
\text { Proyek }\end{array}$ & 8 & Large \\
\hline 11. & $\begin{array}{l}\text { Mengelola Detail Pekerjaan } \\
\text { Proyek }\end{array}$ & 8 & Large \\
\hline 12. & $\begin{array}{l}\text { Laporan Proyek Berdasarkan } \\
\text { Jenis dan Tahapan }\end{array}$ & 5 & Medium \\
\hline 13. & Laporan Pembayaran Proyek & 5 & Medium \\
\hline
\end{tabular}

\begin{tabular}{|c|l|c|l|}
\hline No & Fitur & Bobot & Prioritas \\
\hline 14. & Dashboard Administrator & 8 & Low \\
\hline
\end{tabular}

TABEL II

PRODUCT BACKLOG PIC PROYEK

\begin{tabular}{|c|c|c|c|}
\hline No & Fitur & Bobot & Prioritas \\
\hline 1. & Daftar Proyek Diplot & 3 & Large \\
\hline 2. & $\begin{array}{l}\text { Mengelola } \\
\text { Proyek }\end{array}$ & 5 & Large \\
\hline 3. & $\begin{array}{l}\text { Mengelola Detail Pekerjaan } \\
\text { Proyek }\end{array}$ & 5 & Large \\
\hline 4. & Dashboard PIC Proyek & 5 & Low \\
\hline
\end{tabular}

TABEL III

PRODUCT BACKLOG PELANGGAN

\begin{tabular}{|c|l|c|l|}
\hline No & Fitur & Bobot & Prioritas \\
\hline 1. & Halaman Pencarian Proyek & 3 & Large \\
\hline 2. & Pencarian Proyek & 5 & Large \\
\hline 3. & $\begin{array}{l}\text { Feedback poin-poin pekerjaan } \\
\text { proyek }\end{array}$ & 5 & Medium \\
\hline 4. & Pemberian Penilaian & 3 & Medium \\
\hline
\end{tabular}

\section{Desain Sistem}

Desain sistem pada penelitian ini menggunakan UML. UML yang digunakan yaitu Use Case Diagram dan Class Diagram. Use Case pada sistem di penelitian ini memiliki tiga aktor dan tujuh belas aktivitas. Tiga aktor pada use case yaitu administrator, PIC proyek, dan pelanggan. Sedangkan tujuh belas aktivitas pada use case yaitu Login, Mengelola Jenis Proyek, Mengelola Tahapan Proyek, Mengelola PIC Proyek, Mengelola Hak Akses User, Mengelola Proyek, Mencatat Pembayaran Proyek, Mencetak Kuitansi Pembayaran, Plotting PIC Proyek, Mengelola Daftar Pekerjaan, Mengelola Detail Pekerjaan, Laporan, Dashboard Administrator, Dashboard PIC Proyek, Pencarian Data Proyek, Feedback Hasil Pekerjaan, dan Pemberian Penilaian. Use Case dari penilitian ini dapat dilihat pada Gambar 2.

Class Diagram pada penelitian ini mempunyai sepuluh kelas yang saling berhubungan satu dengan yang lainnya. Sepuluh kelas tersebut yaitu: User, PIC Proyek, Jenis Proyek, Tahapan Proyek, Proyek, PIC Proyek Plot, Pembayaran Proyek, Perkembangan Proyek, Pekerjaan Proyek, dan Pekerjaan ProyekDetail. Class Diagram dari penelitian ini dapat dilihat pada Gambar 3.

\section{Sprint I}

1) Sprint Planning: Target dari sprint pertama yaitu menyelesaikan fitur login, fitur mengelola data master proyek, pengelolaan PIC proyek, pengelolaan hak akses user, dan fitur mengelola data proyek. Sprint backlog untuk sprint pertama dapat dilihat pada Tabel IV. 


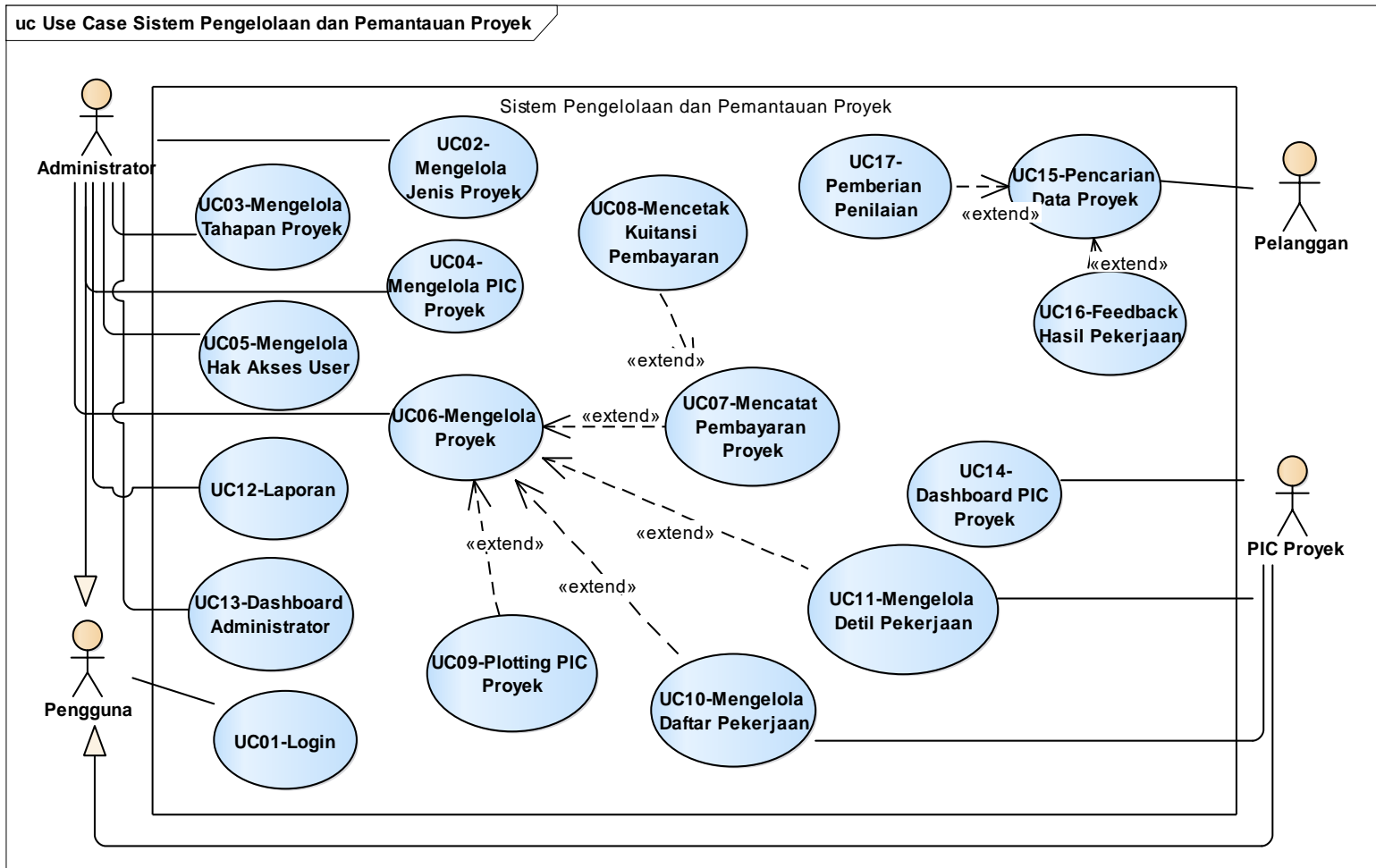

Gambar 2. Use Case Diagram

TABEL IV

SPRINT I BACKLOG

\begin{tabular}{|c|l|c|l|l|}
\hline No & Fitur & Bobot & Prioritas & Status \\
\hline 1. & Login & 5 & Large & Baru \\
\hline 2. & $\begin{array}{l}\text { Mengelola data PIC } \\
\text { proyek }\end{array}$ & 5 & Large & Baru \\
\hline 3. & $\begin{array}{l}\text { Mengelola hak akses } \\
\text { user }\end{array}$ & 5 & Large & Baru \\
\hline 4. & $\begin{array}{l}\text { Mengelola data jenis } \\
\text { proyek }\end{array}$ & 5 & Large & Baru \\
\hline 5. & $\begin{array}{l}\text { Mengelola data tahapan } \\
\text { proyek }\end{array}$ & 5 & Large & Baru \\
\hline 6. & Mengelola data proyek & 8 & Large & Baru \\
\hline
\end{tabular}

2) Testing: Pengujian sistem dilakukan dengan menjalankan skenario pengujian yang sudah dibuat beserta luaran yang diharapkan dari setiap skenario. Daftar skenario dan hasil pengujian dapat dilihat pada Tabel V.

TABEL V

SKenario Pengujian dan Hasil PENGUJian SPRINT I

\begin{tabular}{|c|c|c|c|}
\hline No & Skenario & $\begin{array}{l}\text { Luaran yang } \\
\text { diharapkan }\end{array}$ & Hasil \\
\hline \multicolumn{4}{|c|}{ Login } \\
\hline 1. & $\begin{array}{l}\text { Pengguna } \\
\text { memasukkan email } \\
\text { dan password yang } \\
\text { sesuai. }\end{array}$ & $\begin{array}{l}\text { Pengguna dialihkan } \\
\text { ke halaman utama } \\
\text { aplikasi. }\end{array}$ & Sukses \\
\hline 2. & $\begin{array}{l}\text { Pengguna } \\
\text { memasukkan email }\end{array}$ & $\begin{array}{l}\text { Sistem memunculkan } \\
\text { pesan gagal. }\end{array}$ & Sukses \\
\hline
\end{tabular}

\begin{tabular}{|c|c|c|c|}
\hline No & Skenario & $\begin{array}{l}\text { Luaran yang } \\
\text { diharapkan }\end{array}$ & Hasil \\
\hline & $\begin{array}{l}\text { dan password yang } \\
\text { tidak sesuai. }\end{array}$ & & \\
\hline \multicolumn{4}{|c|}{ Mengelola jenis proyek } \\
\hline 3. & $\begin{array}{l}\text { Administrator } \\
\text { membuka halaman } \\
\text { kelola jenis proyek. }\end{array}$ & $\begin{array}{l}\text { Sistem menampilkan } \\
\text { halaman kelola dan } \\
\text { daftar jenis proyek. }\end{array}$ & Sukses \\
\hline 4. & $\begin{array}{l}\text { Administrator } \\
\text { menambahkan data } \\
\text { jenis proyek }\end{array}$ & $\begin{array}{l}\text { Data tersimpan ke } \\
\text { database dan tampil } \\
\text { di daftar jenis proyek. }\end{array}$ & Sukses \\
\hline 5 . & $\begin{array}{l}\text { Administrator } \\
\text { mengubah data jenis } \\
\text { proyek }\end{array}$ & $\begin{array}{l}\text { Data tersimpan ke } \\
\text { database dan di daftar } \\
\text { jenis proyek data } \\
\text { mengalami perubahan }\end{array}$ & Sukses \\
\hline 6. & $\begin{array}{l}\text { Administrator } \\
\text { menghapus data } \\
\text { jenis proyek }\end{array}$ & $\begin{array}{l}\text { Data terhapus dari } \\
\text { database dan tidak } \\
\text { tampil di daftar jenis } \\
\text { proyek }\end{array}$ & Sukses \\
\hline \multicolumn{4}{|c|}{ Mengelola tahapan proyek } \\
\hline 7. & $\begin{array}{l}\text { Administrator } \\
\text { membuka halaman } \\
\text { kelola tahapan } \\
\text { proyek. }\end{array}$ & $\begin{array}{l}\text { Sistem menampilkan } \\
\text { halaman kelola dan } \\
\text { daftar tahapan proyek. }\end{array}$ & Sukses \\
\hline 8. & $\begin{array}{l}\text { Administrator } \\
\text { menambahkan data } \\
\text { tahapan proyek }\end{array}$ & $\begin{array}{l}\text { Data tersimpan ke } \\
\text { database dan tampil } \\
\text { di daftar tahapan } \\
\text { proyek. }\end{array}$ & Sukses \\
\hline 9. & $\begin{array}{l}\text { Administrator } \\
\text { mengubah data } \\
\text { tahapan proyek }\end{array}$ & $\begin{array}{l}\text { Data tersimpan ke } \\
\text { database dan di daftar } \\
\text { tahapan proyek data } \\
\text { mengalami perubahan }\end{array}$ & Sukses \\
\hline
\end{tabular}




\begin{tabular}{|c|c|c|c|}
\hline No & Skenario & $\begin{array}{l}\text { Luaran yang } \\
\text { diharapkan }\end{array}$ & Hasil \\
\hline 10. & $\begin{array}{l}\text { Administrator } \\
\text { menghapus data } \\
\text { tahapan proyek }\end{array}$ & $\begin{array}{l}\text { Data terhapus dari } \\
\text { database dan tidak } \\
\text { tampil di daftar } \\
\text { tahapan proyek }\end{array}$ & Sukses \\
\hline \multicolumn{4}{|c|}{ Mengelola PIC proyek } \\
\hline 11. & $\begin{array}{l}\text { Administrator } \\
\text { membuka halaman } \\
\text { kelola PIC proyek. }\end{array}$ & $\begin{array}{l}\text { Sistem menampilkan } \\
\text { halaman kelola dan } \\
\text { daftar PIC proyek. }\end{array}$ & Sukses \\
\hline 12. & $\begin{array}{l}\text { Administrator } \\
\text { menambahkan data } \\
\text { PIC proyek }\end{array}$ & $\begin{array}{l}\text { Data tersimpan ke } \\
\text { database dan tampil } \\
\text { di daftar PIC proyek. }\end{array}$ & Sukses \\
\hline 13. & $\begin{array}{l}\text { Administrator } \\
\text { mengubah data PIC } \\
\text { proyek }\end{array}$ & $\begin{array}{l}\text { Data tersimpan ke } \\
\text { database dan di daftar } \\
\text { PIC proyek data } \\
\text { mengalami perubahan }\end{array}$ & Sukses \\
\hline 14. & $\begin{array}{l}\text { Administrator } \\
\text { menghapus data PIC } \\
\text { proyek }\end{array}$ & $\begin{array}{l}\text { Data terhapus dari } \\
\text { database dan tidak } \\
\text { tampil di daftar PIC } \\
\text { proyek }\end{array}$ & Sukses \\
\hline \multicolumn{4}{|c|}{ Mengelola Hak Akses User } \\
\hline 15. & $\begin{array}{l}\text { Administrator } \\
\text { membuka halaman } \\
\text { kelola hak akses } \\
\text { user. }\end{array}$ & $\begin{array}{l}\text { Sistem menampilkan } \\
\text { halaman kelola dan } \\
\text { daftar hak akses user. }\end{array}$ & Sukses \\
\hline 16. & $\begin{array}{l}\text { Administrator } \\
\text { menambahkan data } \\
\text { hak akses user }\end{array}$ & $\begin{array}{l}\text { Data tersimpan ke } \\
\text { database dan tampil } \\
\text { di daftar hak akses }\end{array}$ & Sukses \\
\hline
\end{tabular}

\begin{tabular}{|l|l|l|l|}
\hline No & Skenario & $\begin{array}{l}\text { Luaran yang } \\
\text { diharapkan }\end{array}$ & Hasil \\
\hline 17. & $\begin{array}{l}\text { Administrator } \\
\text { mengubah data hak } \\
\text { akses user }\end{array}$ & $\begin{array}{l}\text { Data tersimpan ke } \\
\text { database dan di daftar } \\
\text { PIC proyek data } \\
\text { mengalami perubahan }\end{array}$ & Sukses \\
\hline 18. & $\begin{array}{l}\text { Administrator } \\
\text { menghapus data hak } \\
\text { akses user }\end{array}$ & $\begin{array}{l}\text { Data terhapus dari } \\
\text { database dan tidak } \\
\text { tampil di daftar hak } \\
\text { akses user }\end{array}$ & Sukses \\
\hline Mengelola Proyek & $\begin{array}{l}\text { Administrator } \\
\text { membuka halaman } \\
\text { kelola proyek. }\end{array}$ & $\begin{array}{l}\text { Sistem menampilkan } \\
\text { halaman kelola dan } \\
\text { daftar proyek. }\end{array}$ & Sukses \\
\hline 19. & $\begin{array}{l}\text { Administrator } \\
\text { menambahkan data } \\
\text { proyek }\end{array}$ & $\begin{array}{l}\text { Data tersimpan ke } \\
\text { database dan tampil } \\
\text { di daftar proyek. }\end{array}$ & Sukses \\
\hline 21. & $\begin{array}{l}\text { Administrator } \\
\text { mengubah data } \\
\text { proyek }\end{array}$ & $\begin{array}{l}\text { Data tersimpan ke } \\
\text { database dan di daftar } \\
\text { proyek data } \\
\text { mengalami perubahan }\end{array}$ & Sukses \\
\hline 22. & $\begin{array}{l}\text { Administrator } \\
\text { menghapus data } \\
\text { proyek }\end{array}$ & $\begin{array}{l}\text { Data terhapus dari } \\
\text { database dan tidak } \\
\text { tampil di daftar } \\
\text { proyek }\end{array}$ & Sukses \\
\hline
\end{tabular}

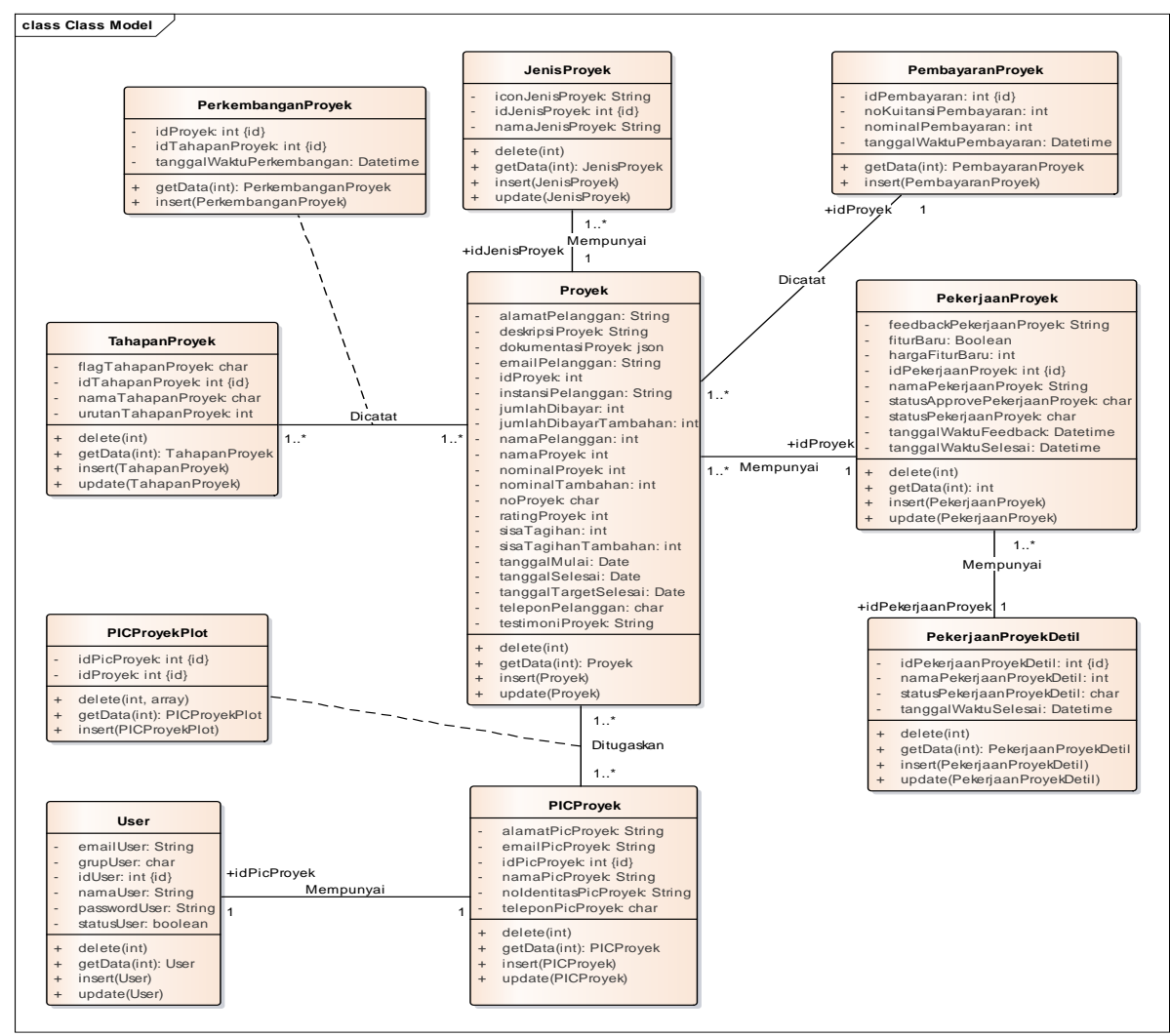

Gambar 3. Class Diagram 
3) Sprint Review: Pada tahap ini dilakukan demonstrasi hasil dari sprint pertama, dan didapatkan hasil review dari pemangku kepentingan yaitu:

- Semua fitur berjalan dengan baik.

- Tampilkan bagus dan responsif.

- Menu yang ditampilkan tidak membingungkan.

- Label dan formulir isian sangat jelas.

4) Deployment: Pada tahap ini dilakukan pemasangan fitur berdasarkan yang telah disetujui oleh pemangku kepentingan untuk dapat digunakan secara langsung. Tampilan antar muka dari fitur yang telah dipasang pada sprint pertama dapat dilihat pada Gambar 4 dan Gambar 5.

\section{E. Sprint II}

1) Sprint Planning: Target dari sprint kedua yaitu menyelesaikan fitur pencatatan pembayaran dan cetak kuitansi pembayaran, plotting PIC proyek, mengelola daftar pekerjaan dan detail pekerjaan, dan laporan daftar proyek berdasarkan jenis proyek dan tahapan proyek. Sprint backlog untuk sprint kedua dapat dilihat pada Tabel VI.
TABEL VI

SPRINT II BACKLOG

\begin{tabular}{|c|l|c|l|l|}
\hline No & Fitur & Bobot & Prioritas & Status \\
\hline 1. & $\begin{array}{l}\text { Mencatat data } \\
\text { pembayaran proyek }\end{array}$ & 3 & Large & Baru \\
\hline 2. & $\begin{array}{l}\text { Mencetak kuitansi } \\
\text { pembayaran }\end{array}$ & 3 & Medium & Baru \\
\hline 3. & Plotting PIC proyek & 8 & Large & Baru \\
\hline 4. & $\begin{array}{l}\text { Mengelola daftar } \\
\text { pekerjaan proyek (sisi } \\
\text { administrator) }\end{array}$ & 8 & Large & Baru \\
\hline 5. & $\begin{array}{l}\text { Mengelola detail } \\
\text { pekerjaan proyek (sisi } \\
\text { administrator) }\end{array}$ & 8 & Large & Baru \\
\hline 6. & $\begin{array}{l}\text { Laporan proyek } \\
\text { berdasarkan jenis dan } \\
\text { tahapan }\end{array}$ & 5 & Medium & Baru \\
\hline
\end{tabular}

2) Testing: Pengujian sistem dilakukan dengan menjalankan skenario pengujian yang sudah dibuat beserta luaran yang diharapkan dari setiap skenario. Daftar skenario dan hasil pengujian dapat dilihat pada Tabel VII.

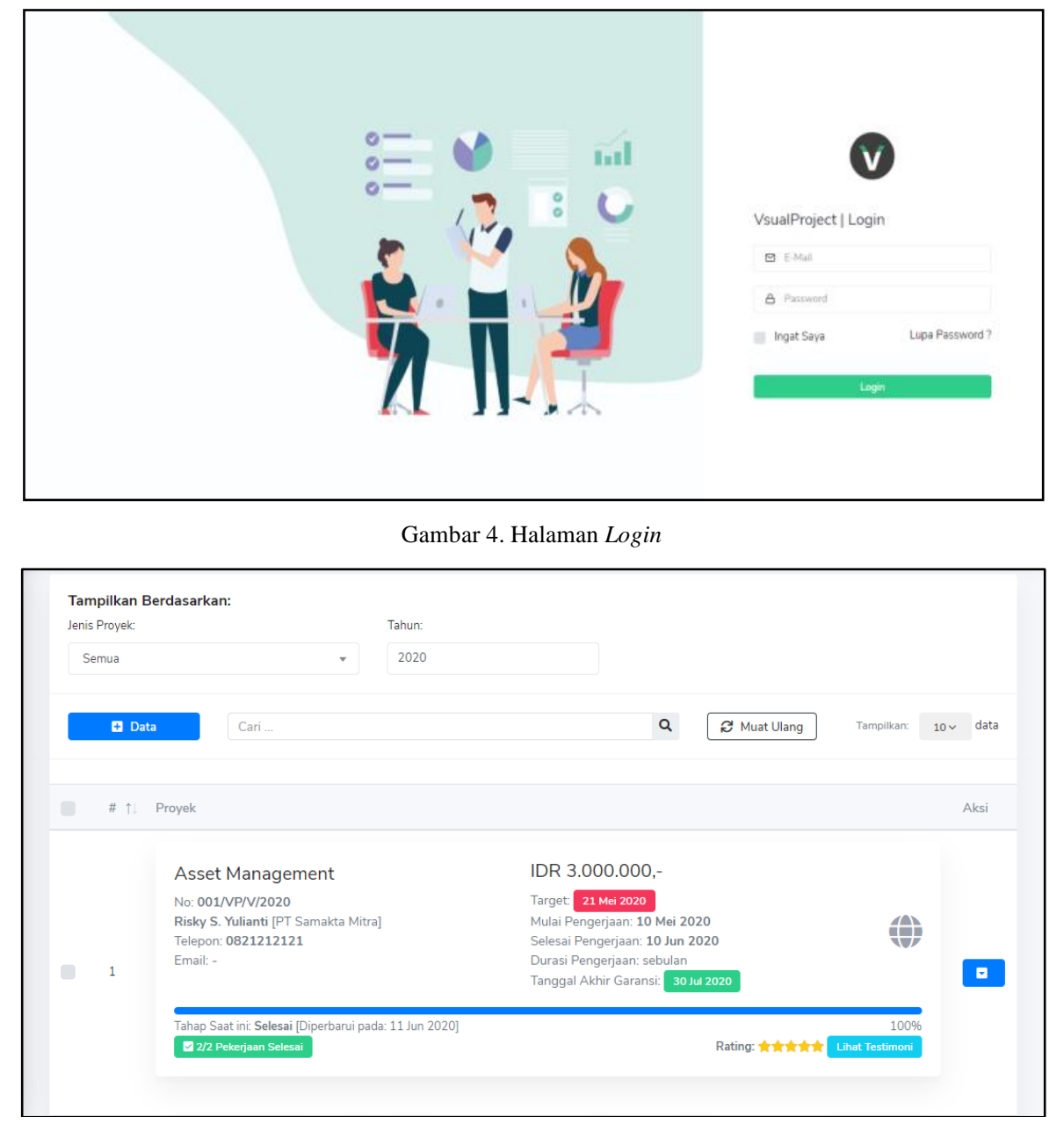

Gambar 5. Halaman Kelola Proyek 
TABEL VII

SKENARIO PENGUJIAN DAN HASIL PENGUJIAN SPRINT II

\begin{tabular}{|c|c|c|c|}
\hline No & Skenario & $\begin{array}{l}\text { Luaran yang } \\
\text { diharapkan }\end{array}$ & Hasil \\
\hline \multicolumn{4}{|c|}{ Mencatat data pembayaran proyek } \\
\hline 1. & $\begin{array}{l}\text { Administrator } \\
\text { membuka aksi data } \\
\text { pembayaran proyek } \\
\text { pada halaman kelola } \\
\text { proyek }\end{array}$ & $\begin{array}{l}\text { Memunculkan daftar } \\
\text { riwayat pembayaran } \\
\text { dan sisa tagihan } \\
\text { proyek }\end{array}$ & Sukses \\
\hline 2. & $\begin{array}{l}\text { Administrator } \\
\text { menambahkan data } \\
\text { pembayaran }\end{array}$ & $\begin{array}{l}\text { Data tersimpan di } \\
\text { database dan tampil di } \\
\text { daftar riwayat } \\
\text { pembayaran }\end{array}$ & Sukses \\
\hline \multicolumn{4}{|c|}{ Mencetak Kuitansi Pembayaran } \\
\hline 3. & $\begin{array}{l}\text { Administrator } \\
\text { memilih data } \\
\text { pembayaran proyek } \\
\text { dari riwayat } \\
\text { pembayaran yang } \\
\text { akan dicetak. }\end{array}$ & $\begin{array}{l}\text { Sistem menampilkan } \\
\text { pratinjau kuitansi } \\
\text { pembayaran proyek }\end{array}$ & Sukses \\
\hline \multicolumn{4}{|c|}{ Plotting PIC proyek } \\
\hline 4. & $\begin{array}{l}\text { Administrator } \\
\text { membuka aksi } \\
\text { plotting PIC pada } \\
\text { halaman kelola } \\
\text { proyek }\end{array}$ & $\begin{array}{l}\text { Sistem menampilkan } \\
\text { halaman plotting PIC } \\
\text { proyek. }\end{array}$ & Sukses \\
\hline 5. & $\begin{array}{l}\text { Administrator } \\
\text { melakukan plot PIC } \\
\text { Proyek pada proyek }\end{array}$ & $\begin{array}{l}\text { Data tersimpan ke } \\
\text { database dan tampil } \\
\text { di daftar PIC proyek } \\
\text { diplot. }\end{array}$ & Sukses \\
\hline 6. & $\begin{array}{l}\text { Administrator } \\
\text { menghapus data } \\
\text { plot PIC Proyek } \\
\text { pada proyek }\end{array}$ & $\begin{array}{l}\text { Data terhapus dari } \\
\text { database dan tidak } \\
\text { tampil di daftar di PIC } \\
\text { proyek diplot. }\end{array}$ & Sukses \\
\hline \multicolumn{4}{|c|}{ Mengelola daftar pekerjaan proyek (sisi administrator) } \\
\hline 7. & $\begin{array}{l}\text { Administrator } \\
\text { membuka aksi } \\
\text { kelola pekerjaan } \\
\text { pada halaman kelola } \\
\text { proyek }\end{array}$ & $\begin{array}{l}\text { Sistem menampilkan } \\
\text { halaman kelola } \\
\text { pekerjaan proyek. }\end{array}$ & Sukses \\
\hline 8. & $\begin{array}{l}\text { Administrator } \\
\text { menambahkan data } \\
\text { pekerjaan }\end{array}$ & $\begin{array}{l}\text { Data tersimpan ke } \\
\text { database dan tampil } \\
\text { di daftar pekerjaan } \\
\text { proyek. }\end{array}$ & Sukses \\
\hline 9. & $\begin{array}{l}\text { Administrator } \\
\text { mengubah data } \\
\text { pekerjaan }\end{array}$ & $\begin{array}{l}\text { Data tersimpan ke } \\
\text { database dan di daftar } \\
\text { pekerjaan proyek data } \\
\text { mengalami perubahan }\end{array}$ & Sukses \\
\hline 10. & $\begin{array}{l}\text { Administrator } \\
\text { menghapus data } \\
\text { pekerjaan }\end{array}$ & $\begin{array}{l}\text { Data terhapus dari } \\
\text { database dan tidak } \\
\text { tampil di daftar di } \\
\text { pekerjaan proyek. }\end{array}$ & Sukses \\
\hline \multicolumn{4}{|c|}{ Mengelola detail pekerjaan proyek (sisi administrator) } \\
\hline 11. & $\begin{array}{l}\text { Administrator } \\
\text { membuka aksi } \\
\text { kelola detail } \\
\text { pekerjaan pada } \\
\text { halaman kelola }\end{array}$ & $\begin{array}{l}\text { Sistem menampilkan } \\
\text { halaman kelola detail } \\
\text { pekerjaan proyek. }\end{array}$ & Sukses \\
\hline
\end{tabular}

\begin{tabular}{|c|c|c|c|}
\hline No & Skenario & $\begin{array}{l}\text { Luaran yang } \\
\text { diharapkan }\end{array}$ & Hasil \\
\hline & pekerjaan & & \\
\hline 12. & $\begin{array}{l}\text { Administrator } \\
\text { menambahkan data } \\
\text { detail pekerjaan }\end{array}$ & $\begin{array}{l}\text { Data tersimpan ke } \\
\text { database dan tampil } \\
\text { di daftar detail } \\
\text { pekerjaan proyek. }\end{array}$ & Sukses \\
\hline 13. & $\begin{array}{l}\text { Administrator } \\
\text { mengubah data } \\
\text { detail pekerjaan }\end{array}$ & $\begin{array}{l}\text { Data tersimpan ke } \\
\text { database dan di daftar } \\
\text { detail pekerjaan } \\
\text { proyek data } \\
\text { mengalami perubahan }\end{array}$ & Sukses \\
\hline 14. & $\begin{array}{l}\text { Administrator } \\
\text { menghapus data } \\
\text { detail pekerjaan }\end{array}$ & $\begin{array}{l}\text { Data terhapus dari } \\
\text { database dan tidak } \\
\text { tampil di daftar di } \\
\text { detail pekerjaan } \\
\text { proyek. }\end{array}$ & Sukses \\
\hline \multicolumn{4}{|c|}{ Laporan proyek berdasarkan jenis dan tahapan } \\
\hline 15. & $\begin{array}{l}\text { Administrator } \\
\text { membuka halaman } \\
\text { laporan berdasarkan } \\
\text { jenis dan tahapan }\end{array}$ & $\begin{array}{l}\text { Sistem menampilkan } \\
\text { halaman dan daftar } \\
\text { proyek berdasarkan } \\
\text { jenis dan tahapan } \\
\text { yang dipilih }\end{array}$ & Sukses \\
\hline 16. & $\begin{array}{l}\text { Administrator } \\
\text { mencetak laporan } \\
\text { berdasarkan jenis } \\
\text { dan tahapan }\end{array}$ & $\begin{array}{l}\text { Sistem menampilkan } \\
\text { pratinjau laporan }\end{array}$ & Sukses \\
\hline
\end{tabular}

3) Sprint Review: Pada tahap ini dilakukan demonstrasi hasil dari sprint kedua, dan didapatkan hasil review dari pemangku kepentingan yaitu:

- Semua fitur berjalan dengan baik.

- Fitur pengelolaan pekerjaan proyek dan detail pekerjaan interaktif.

- Desain kuitansi jelas dan informatif

- Minta penambahan laporan untuk daftar PIC proyek yang sudah diplot di setiap proyek.

4) Deployment: Pada tahap ini dilakukan pemasangan fitur berdasarkan yang telah disetujui oleh pemangku kepentingan untuk dapat digunakan secara langsung. Tampilan antar muka dari fitur yang telah dipasang pada sprint kedua dapat dilihat pada Gambar 6 dan Gambar 7 .

\section{F. Sprint III}

1) Sprint Planning: Target dari sprint ketiga yaitu menyelesaikan fitur laporan pembayaran proyek, dashboard sisi administrator dan fitur yang terdapat pada sisi PIC proyek yaitu: daftar proyek diplot, mengelola daftar pekerjaan, mengelola detail pekerjaan, dan dashboard sisi PIC proyek. Pada review sprint kedua didapatkan satu tambahan menu laporan yaitu laporan daftar PIC proyek dari setiap proyek. Tambahan tersebut akan dikerjakan pada sprint ketiga. Sprint backlog untuk sprint ketiga dapat dilihat pada Tabel VIII. 
Riwayat Pembayaran

\section{\# No.Kuitansi Waktu}

Nominal (IDR)

Catatan

Aksi

120.006

22 Jul 2020 23:51

$3.000 .000,-$

8

Rincian Tagihan:

Nominal Proyek

5.000 .000

Jumlah Dibayar

3.000 .000

Sisa Tagihan

2.000 .000

+ Pembayaran

Tutup

Gambar 6. Halaman Kelola Pembayaran

Kelola Pekerjaan

Tampilkan Berdasarkan:

Prioritas:

Status:

SEMUA

SEMUA

+ Pekerjaan

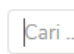

Kari...

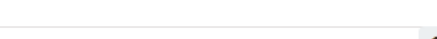

Q

₹ Muat Ulang Tampilkan: 10v data

Gambar 7. Halaman Kelola Pekerjaan Proyek

TABEL VIII

SPRINT III BACKLOG

\begin{tabular}{|c|l|c|l|l|}
\hline No & Fitur & Bobot & Prioritas & Status \\
\hline 1. & $\begin{array}{l}\text { Laporan pembayaran } \\
\text { proyek }\end{array}$ & 5 & Medium & Baru \\
\hline 2. & $\begin{array}{l}\text { Laporan plot PIC } \\
\text { Proyek }\end{array}$ & 5 & Medium & $\begin{array}{l}\text { Tamb } \\
\text { ahan }\end{array}$ \\
\hline 3. & $\begin{array}{l}\text { Dashboard } \\
\text { administrator }\end{array}$ & 8 & Low & Baru \\
\hline
\end{tabular}

\begin{tabular}{|c|l|c|l|l|}
\hline No & Fitur & Bobot & Prioritas & Status \\
\hline 4. & $\begin{array}{l}\text { Daftar proyek diplot } \\
\text { (sisi PIC proyek) }\end{array}$ & 3 & Large & Baru \\
\hline 5. & $\begin{array}{l}\text { Mengelola daftar } \\
\text { pekerjaan proyek (sisi } \\
\text { PIC proyek) }\end{array}$ & 5 & Large & Baru \\
\hline 6. & $\begin{array}{l}\text { Mengelola detail } \\
\text { pekerjaan proyek (sisi } \\
\text { PIC Proyek) }\end{array}$ & 5 & Large & Baru \\
\hline 7. & Dashboard PIC proyek & 5 & Low & Baru \\
\hline
\end{tabular}


2) Testing: Pengujian sistem dilakukan dengan menjalankan skenario pengujian yang sudah dibuat beserta luaran yang diharapkan dari setiap skenario. Daftar skenario dan hasil pengujian dapat dilihat pada Tabel IX.

TABEL IX

SKENARio PENGUJian DAN HASIL PENGUJiAn SPRINT III

\begin{tabular}{|c|c|c|c|}
\hline No & Skenario & $\begin{array}{l}\text { Luaran yang } \\
\text { diharapkan }\end{array}$ & Hasil \\
\hline \multicolumn{4}{|c|}{ Laporan pembayaran proyek } \\
\hline 1. & $\begin{array}{l}\text { Administrator } \\
\text { membuka halaman } \\
\text { laporan pembayaran } \\
\text { proyek }\end{array}$ & $\begin{array}{l}\text { Sistem menampilkan } \\
\text { halaman laporan } \\
\text { pembayaran proyek }\end{array}$ & Sukses \\
\hline 2. & $\begin{array}{l}\text { Administrator } \\
\text { mencetak laporan } \\
\text { pembavaran provek }\end{array}$ & $\begin{array}{l}\text { Sistem menampilkan } \\
\text { pratinjau laporan }\end{array}$ & Sukses \\
\hline \multicolumn{4}{|c|}{ Laporan plot PIC proyek } \\
\hline 3. & $\begin{array}{l}\text { Administrator } \\
\text { membuka halaman } \\
\text { laporan plot PIC } \\
\text { proyek }\end{array}$ & $\begin{array}{l}\text { Sistem menampilkan } \\
\text { halaman laporan plot } \\
\text { PIC proyek }\end{array}$ & Sukses \\
\hline 4. & $\begin{array}{l}\text { Administrator } \\
\text { mencetak laporan } \\
\text { plot PIC proyek }\end{array}$ & $\begin{array}{l}\text { Sistem menampilkan } \\
\text { pratinjau laporan }\end{array}$ & \\
\hline \multicolumn{4}{|c|}{ Dashboard administrator } \\
\hline 5. & $\begin{array}{l}\text { Administrator } \\
\text { membuka halaman } \\
\text { dashboard }\end{array}$ & $\begin{array}{l}\text { Sistem menampilkan } \\
\text { halaman dashboard } \\
\text { dan data yang sesuai } \\
\text { dengan jenis } \\
\text { pengguna } \\
\text { administrator }\end{array}$ & Sukses \\
\hline \multicolumn{4}{|c|}{ Daftar proyek diplot (sisi PIC proyek) } \\
\hline 6. & $\begin{array}{l}\text { PIC Proyek } \\
\text { membuka halaman } \\
\text { kelola proyek }\end{array}$ & $\begin{array}{l}\text { Sistem menampilkan } \\
\text { halaman kelola } \\
\text { proyek dan daftar } \\
\text { proyek sesuai data } \\
\text { plot PIC proyek }\end{array}$ & Sukses \\
\hline \multicolumn{4}{|c|}{ Mengelola daftar pekerjaan proyek (sisi PIC proyek) } \\
\hline 7. & $\begin{array}{l}\text { PIC Proyek } \\
\text { membuka aksi } \\
\text { kelola pekerjaan } \\
\text { pada halaman kelola } \\
\text { proyek }\end{array}$ & $\begin{array}{l}\text { Sistem menampilkan } \\
\text { halaman kelola } \\
\text { pekerjaan proyek. }\end{array}$ & Sukses \\
\hline 8. & $\begin{array}{l}\text { PIC Proyek } \\
\text { menambahkan data } \\
\text { pekerjaan }\end{array}$ & $\begin{array}{l}\text { Data tersimpan ke } \\
\text { database dan tampil } \\
\text { di daftar pekerjaan } \\
\text { proyek. }\end{array}$ & Sukses \\
\hline 9. & $\begin{array}{l}\text { PIC Proyek } \\
\text { mengubah data } \\
\text { pekerjaan }\end{array}$ & $\begin{array}{l}\text { Data tersimpan ke } \\
\text { database dan di daftar } \\
\text { pekerjaan proyek data } \\
\text { mengalami perubahan }\end{array}$ & Sukses \\
\hline 10. & $\begin{array}{l}\text { PIC Proyek } \\
\text { menghapus data } \\
\text { pekerjaan }\end{array}$ & $\begin{array}{l}\text { Data terhapus dari } \\
\text { database dan tidak } \\
\text { tampil di daftar di } \\
\text { pekerjaan proyek. }\end{array}$ & Sukses \\
\hline \multicolumn{4}{|c|}{ Mengelola detail pekerjaan proyek (sisi PIC proyek) } \\
\hline 11. & $\begin{array}{l}\text { PIC Proyek } \\
\text { membuka aksi } \\
\text { kelola detail } \\
\text { pekerjaan pada }\end{array}$ & $\begin{array}{l}\text { Sistem menampilkan } \\
\text { halaman kelola detail } \\
\text { pekerjaan proyek. }\end{array}$ & Sukses \\
\hline
\end{tabular}

\begin{tabular}{|c|c|c|c|}
\hline No & Skenario & $\begin{array}{l}\text { Luaran yang } \\
\text { diharapkan }\end{array}$ & Hasil \\
\hline & $\begin{array}{l}\text { halaman kelola } \\
\text { pekerjaan }\end{array}$ & & \\
\hline 12. & $\begin{array}{l}\text { PIC Proyek } \\
\text { menambahkan data } \\
\text { detail pekerjaan }\end{array}$ & $\begin{array}{l}\text { Data tersimpan ke } \\
\text { database dan tampil } \\
\text { di daftar detail } \\
\text { pekerjaan proyek. }\end{array}$ & Sukses \\
\hline 13. & $\begin{array}{l}\text { PIC Proyek } \\
\text { mengubah data } \\
\text { detail pekerjaan }\end{array}$ & $\begin{array}{l}\text { Data tersimpan ke } \\
\text { database dan di daftar } \\
\text { detail pekerjaan } \\
\text { proyek data } \\
\text { mengalami perubahan }\end{array}$ & Sukses \\
\hline 14. & $\begin{array}{l}\text { PIC Proyek } \\
\text { menghapus data } \\
\text { detail pekerjaan }\end{array}$ & $\begin{array}{l}\text { Data terhapus dari } \\
\text { database dan tidak } \\
\text { tampil di daftar di } \\
\text { detail pekerjaan } \\
\text { proyek. }\end{array}$ & Sukses \\
\hline \multicolumn{4}{|c|}{ Dashboard PIC proyek } \\
\hline 15. & $\begin{array}{l}\text { PIC Proyek } \\
\text { membuka halaman } \\
\text { dashboard }\end{array}$ & $\begin{array}{l}\text { Sistem menampilkan } \\
\text { halaman dashboard } \\
\text { dan data yang sesuai } \\
\text { dengan jenis } \\
\text { pengguna PIC Proyek }\end{array}$ & Sukses \\
\hline
\end{tabular}

3) Sprint Review: Pada tahap ini dilakukan demonstrasi hasil dari sprint ketiga, dan didapatkan hasil review dari pemangku kepentingan yaitu:

- Semua fitur berjalan dengan baik.

- Desain dashboard sudah menampilkan data yang ada pada sistem.

- Penambahan untuk melihat timeline tahapan setiap proyek pada halaman kelola proyek.

4) Deployment: Pada tahap ini dilakukan pemasangan fitur berdasarkan yang telah disetujui oleh pemangku kepentingan untuk dapat digunakan secara langsung. Tampilan antar muka dari fitur yang telah dipasang pada sprint ketiga dapat dilihat pada Gambar 8 dan Gambar 9.

\section{G. Sprint IV}

1) Sprint Planning: Target dari sprint keempat yaitu menyelesaikan fitur dari sisi pelanggan yaitu halaman pencarian proyek dengan nomor proyek, hasil pencarian proyek dengan nomor proyek, feedback hasil pekerjaan proyek, dan pemberian penilaian. Pada review sprint ketiga didapatkan satu tambahan fitur yaitu melihat timeline tahapan untuk setiap proyek. Tambahan tersebut akan dikerjakan pada sprint keempat. Sprint backlog untuk sprint keempat dapat dilihat pada Tabel $\mathrm{X}$.

TABEL X

SPRINT IV BACKLOG

\begin{tabular}{|c|l|c|l|l|}
\hline No & Fitur & Bobot & Prioritas & Status \\
\hline 1. & $\begin{array}{l}\text { Melihat timeline } \\
\text { tahapan per proyek }\end{array}$ & 3 & Medium & $\begin{array}{l}\text { Tamb } \\
\text { ahan }\end{array}$ \\
\hline 2. & $\begin{array}{l}\text { Halaman pencarian } \\
\text { proyek dengan nomor }\end{array}$ & 3 & Large & Baru \\
\hline
\end{tabular}




\begin{tabular}{|l|l|c|l|l|}
\hline & proyek & & & \\
\hline 3. & $\begin{array}{l}\text { Pencarian Proyek } \\
\text { dengan nomor proyek }\end{array}$ & 5 & Large & Baru \\
\hline
\end{tabular}

\begin{tabular}{|c|c|c|l|l|}
\hline 4. & $\begin{array}{c}\text { Feedback poin-poin } \\
\text { pekerjaan proyek }\end{array}$ & 5 & Medium & Baru \\
\hline 5. & Pemberian penilaian & 3 & Medium & Baru \\
\hline
\end{tabular}

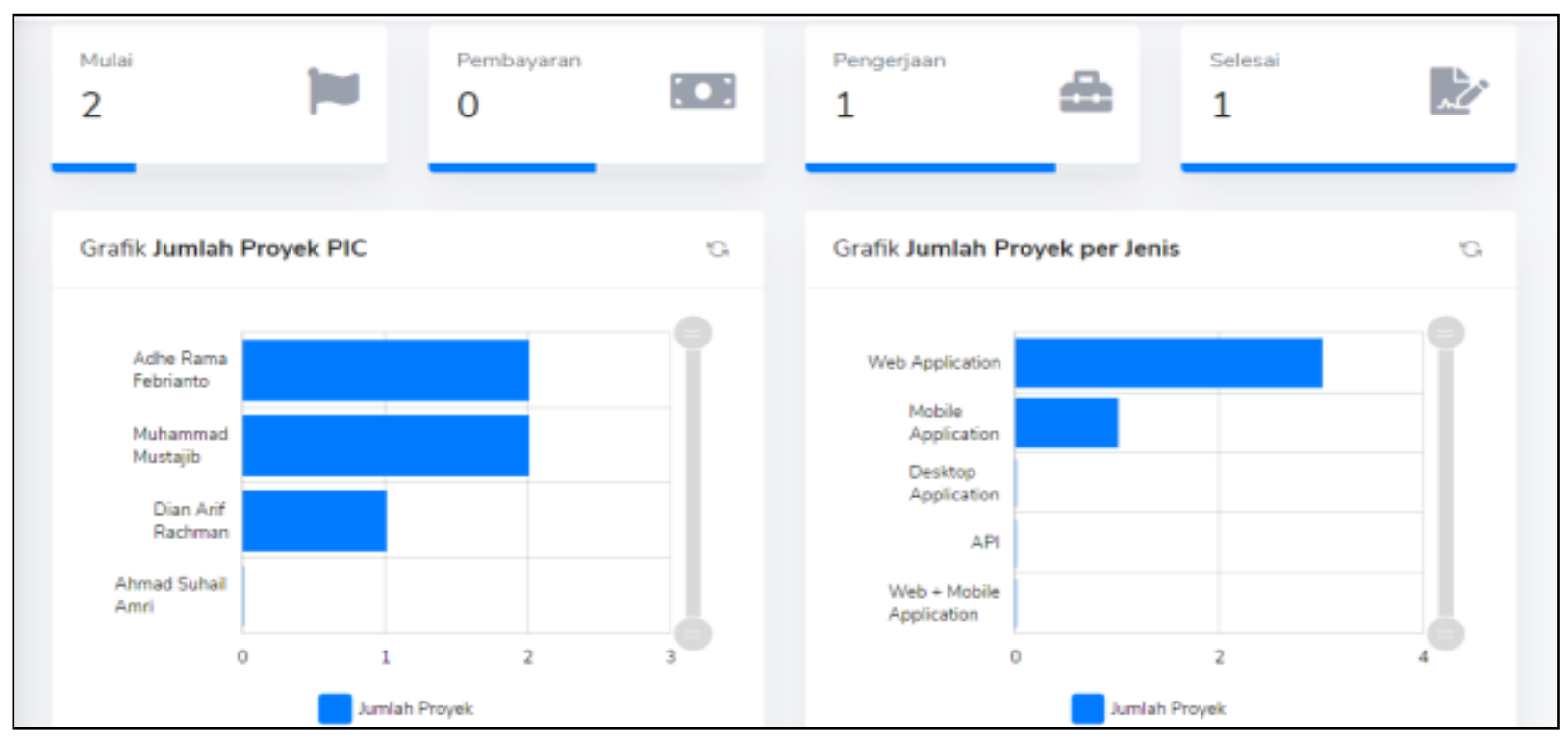

Gambar 8. Halaman Dashboard Administrator

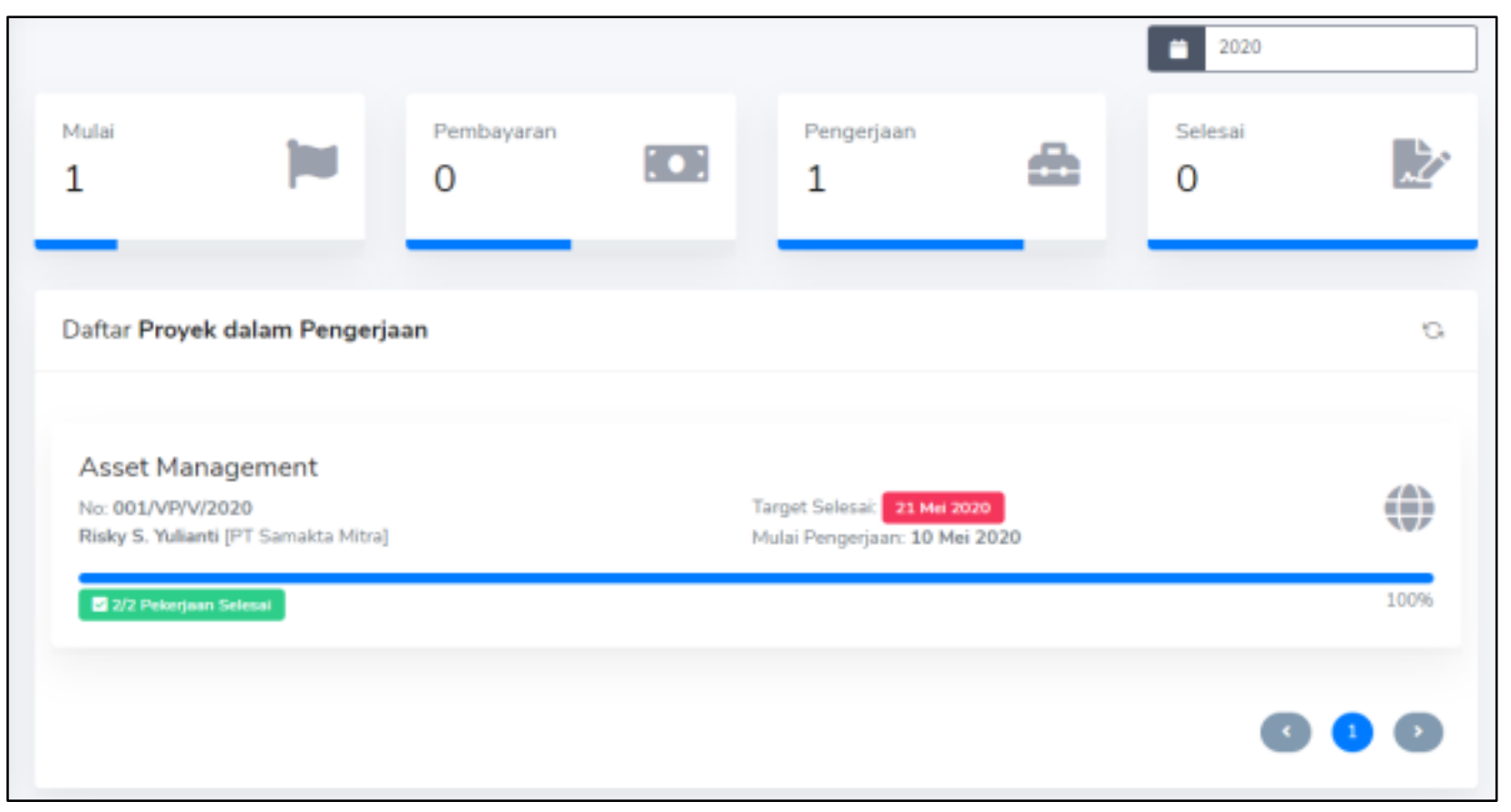

Gambar 9. Halaman Dashboard PIC Proyek

2) Testing: Pengujian sistem dilakukan dengan menjalankan skenario pengujian yang sudah dibuat beserta luaran yang diharapkan dari setiap skenario. Daftar skenario dan hasil pengujian dapat dilihat pada Tabel XI.
TABEL XI

SKENARIO PENGUJIAN DAN HASIL PENGUJIAN SPRINT IV

\begin{tabular}{|l|l|l|l|}
\hline No & Skenario & $\begin{array}{l}\text { Luaran yang } \\
\text { diharapkan }\end{array}$ & Hasil \\
\hline \multicolumn{3}{|l|}{ Melihat timeline per proyek } \\
\hline 1. & $\begin{array}{l}\text { Administrator } \\
\text { membuka aksi }\end{array}$ & $\begin{array}{l}\text { Sistem menampilkan } \\
\text { halaman timeline }\end{array}$ & Sukses \\
\hline
\end{tabular}




\begin{tabular}{|c|c|c|c|}
\hline & $\begin{array}{l}\text { timeline tahapan pada } \\
\text { halaman kelola } \\
\text { proyek }\end{array}$ & $\begin{array}{l}\text { tahapan dari proyek } \\
\text { yang dipilih }\end{array}$ & \\
\hline \multicolumn{4}{|c|}{ Halaman pencarian proyek dengan nomor proyek } \\
\hline 2. & $\begin{array}{l}\text { Pelanggan } \\
\text { memasukkan alamat } \\
\text { web untuk pencarian } \\
\text { proyek }\end{array}$ & $\begin{array}{l}\text { Sistem menampilkan } \\
\text { halaman pencarian } \\
\text { proyek }\end{array}$ & Sukses \\
\hline \multicolumn{4}{|c|}{ Pencarian proyek dengan nomor proyek } \\
\hline 3. & $\begin{array}{l}\text { Pelanggan } \\
\text { memasukkan nomor } \\
\text { proyek }\end{array}$ & $\begin{array}{l}\text { Sistem menampilkan } \\
\text { informasi proyek } \\
\text { yang dicari }\end{array}$ & Sukses \\
\hline \multicolumn{4}{|c|}{ Feedback poin-poin pekerjaan proyek } \\
\hline 4. & $\begin{array}{l}\text { Pelanggan membuka } \\
\text { bagian proses } \\
\text { pengerjaan pada } \\
\text { halaman hasil } \\
\text { pencarian }\end{array}$ & $\begin{array}{l}\text { Sistem menampilkan } \\
\text { bagian pengerjaan dan } \\
\text { daftar pekerjaan dari } \\
\text { proyek }\end{array}$ & Sukses \\
\hline 5. & $\begin{array}{l}\text { Pelanggan mengisi } \\
\text { feedback pada } \\
\text { pekerjaan dan submit } \\
\text { feedback }\end{array}$ & $\begin{array}{l}\text { Data tersimpan ke } \\
\text { database dan sistem } \\
\text { menampilkan } \\
\text { notifikasi berhasil }\end{array}$ & Sukses \\
\hline \multicolumn{4}{|c|}{ Pemberian penilaian } \\
\hline 6. & $\begin{array}{l}\text { Pelanggan membuka } \\
\text { bagian tahapan }\end{array}$ & $\begin{array}{l}\text { Sistem menampilkan } \\
\text { bagian tahapan selesai }\end{array}$ & Sukses \\
\hline
\end{tabular}

\begin{tabular}{|l|l|l|l|}
\hline & $\begin{array}{l}\text { selesai pada halaman } \\
\text { hasil pencarian }\end{array}$ & $\begin{array}{l}\text { berupa formulir isian } \\
\text { penilaian }\end{array}$ & Sukses \\
\hline 7. & $\begin{array}{l}\text { Pelanggan mengisi } \\
\text { dan submit penilaian }\end{array}$ & $\begin{array}{l}\text { Data tersimpan ke } \\
\text { database dan sistem } \\
\text { menampilkan } \\
\text { notifikasi berhasil }\end{array}$ & \\
\hline
\end{tabular}

3) Sprint Review: Pada tahap ini dilakukan demonstrasi hasil dari sprint ketiga, dan didapatkan hasil review dari pemangku kepentingan yaitu:

- Semua fitur yang dipasang berjalan dengan baik.

- Desain halaman pencarian informatif dan memudahkan pelanggan.

- Informasi timeline tahapan proyek informatif.

4) Deployment: Pada tahap ini dilakukan pemasangan fitur berdasarkan yang telah disetujui oleh pemangku kepentingan untuk dapat digunakan secara langsung. Tampilan antar muka dari fitur yang telah dipasang pada sprint keempat dapat dilihat pada Gambar 10, Gambar 11, dan Gambar 12.

\section{PROJECT TRACKING}

Cek perkembangan dan masa garansi proyek anda di halaman ini

NOMOR PROYEK:

Ketik nomor proyek anda di sini... 


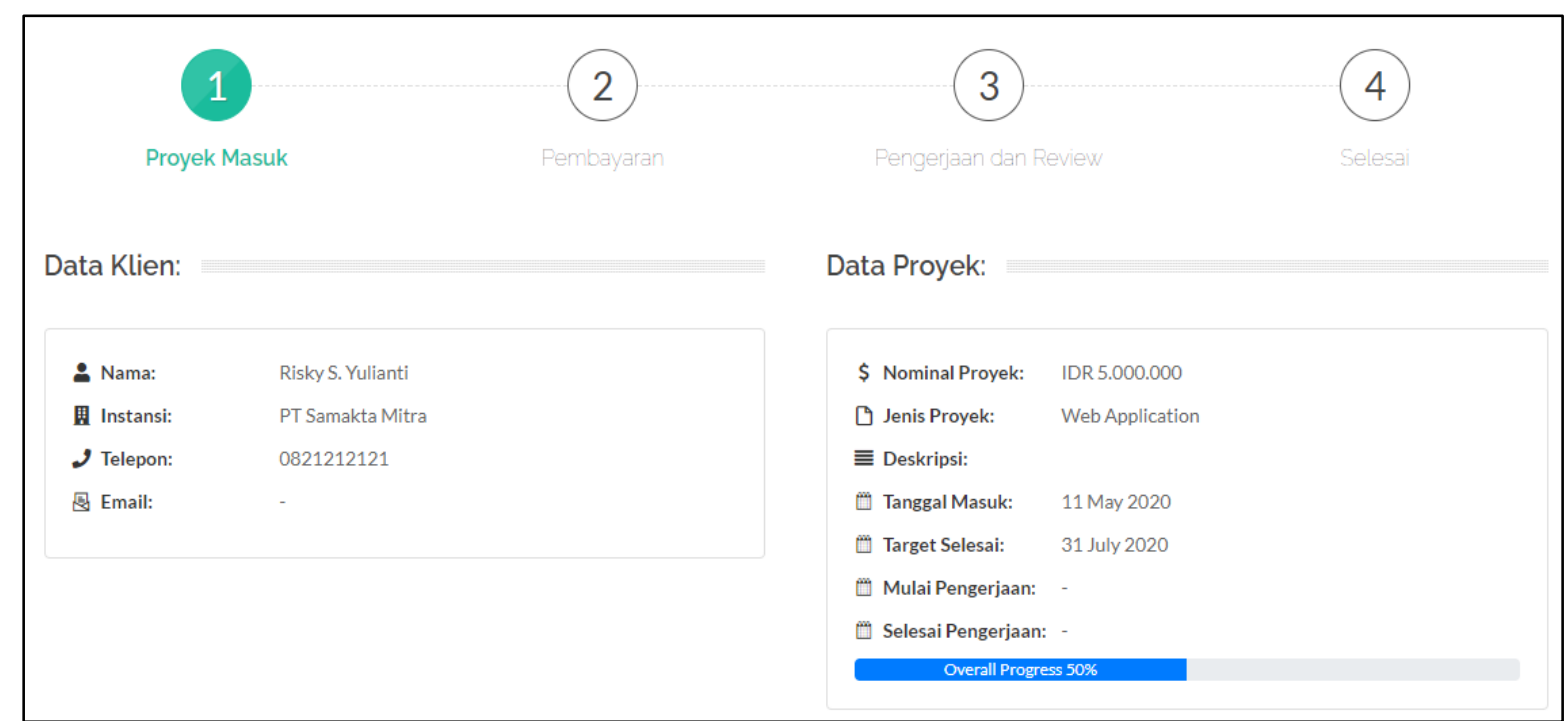

Gambar 11. Halaman Hasil Pencarian Proyek

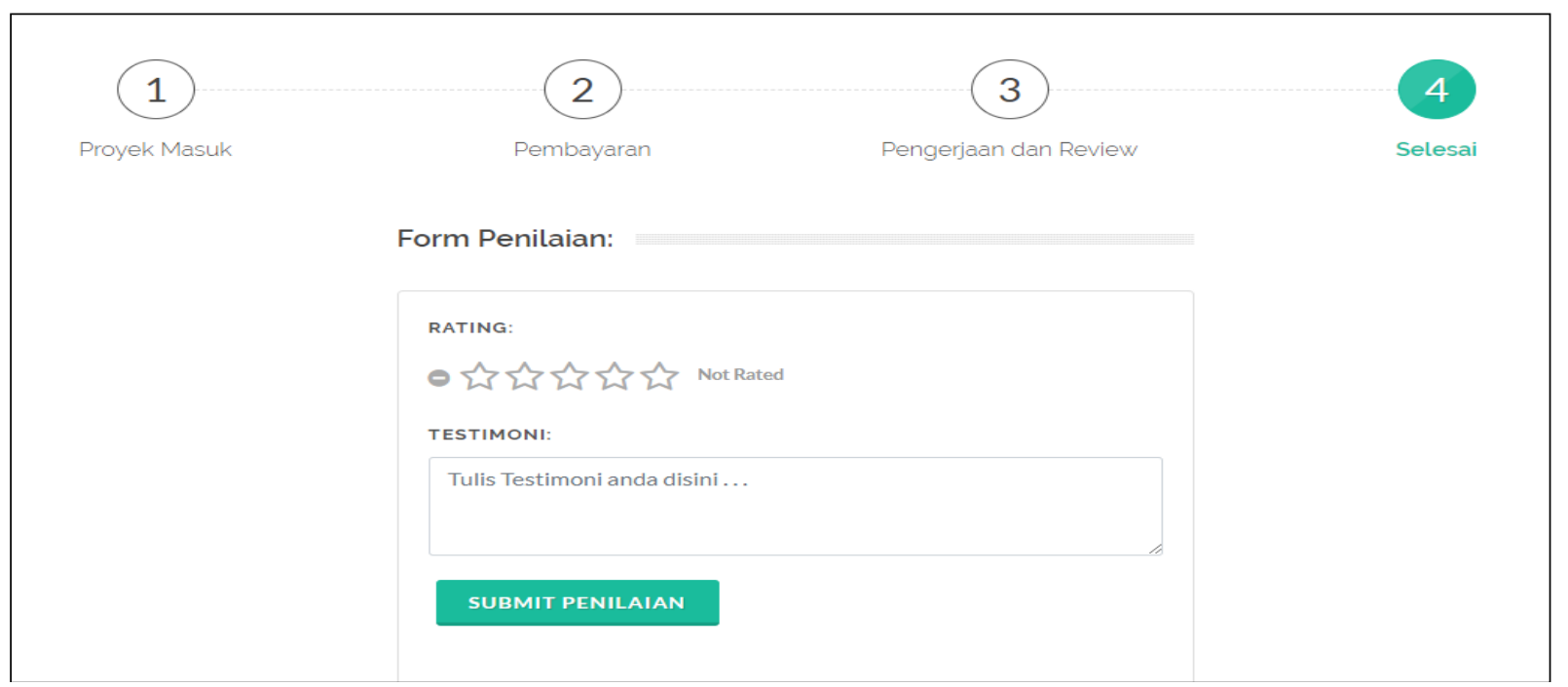

Gambar 12. Halaman Pemberian Penilaian

\section{KESIMPULAN}

Berdasarkan penelitian yang sudah dilakukan dapat diperoleh tiga kesimpulan. Pertama, sistem pengelolaan proyek mampu membantu administrator Visi Prima Group untuk mengelola proyek serta mendapatkan berbagai laporan terkait proyek, dan dapat membantu PIC proyek dari Visi Prima Group untuk mengelola pekerjaan dan detail pekerjaan proyek. Kedua, sistem pemantauan perkembangan proyek mampu membantu pelanggan untuk memantau perkembangan proyeknya dan menjadi nilai tambah Visi Prima Group dalam hal pelayanan. Ketiga, pengembangan sistem menggunakan Agile Development Method dengan pola pendekatan Scrum mempermudah untuk pengembang lebih cepat mendapatkan ulasan dari fitur-fitur yang dikerjakan, dan sistem dapat langsung dipakai oleh Visi Prima Group karena proses deployment yang dilakukan di setiap akhir sprint.

\section{UCAPAN TERIMA KASIH}

Terimakasih saya ucapkan kepada pembimbing saya yaitu Ibu Latipah dan Ibu Anita Wulansari yang telah membimbing saya sehingga dapat menyelesaikan penelitian ini. Terimakasih kepada Visi Prima Group yang telah memberikan izin kepada saya untuk melakukan penelitian dengan studi kasus sistem pada Visi Prima Group.

\section{DAFTAR PUSTAKa}

[1] F. Panggabean, "Mengenal Bisnis Software House di Semarang," 2017. [Online]. Available: https://rectmedia.com/mengenal-bisnissoftware-house-di-semarang/. [Accessed: 18-Sep-2019].

[2] I. Sommerville, Software Engineering, 9th ed. Boston, Mass: Addison-Wesley, 2009.

[3] A. R. Dhuha, F. Pradana, and B. Priyambadha, "Pengembangan Sistem Aplikasi Manajemen Proyek Berbasis Web (Studi Kasus : PT . Swadaya Graha )," J. Pengemb. Teknol. Inf. dan Ilmu Komput. Univ. Brawijaya, vol. 1, no. 11, pp. 1367-1375, 2017. 
[4] D. Paramita, "Rancang Bangun Sistem Informasi Kolaboratif Berbasis Web Untuk Manajemen Proyek Teknologi Informasi," J. Buana Inform., vol. 6, no. 3, pp. 195-202, 2015.

[5] K. Ramanda, "Sistem Informasi Manajemen Proyek Berbasis Web," Indones. J. Netw. Secur., vol. 6, no. 4, pp. 14-17, 2017.

[6] T. Sumitra and M. A. Sutina, "Sistem Informasi Manajemen Proyek pada PT. Sempana Pratama Menggunakan PHP \& My SQL," J. Sibernetika, vol. 2, no. 1, pp. 86-93, 2017.

[7] M. J. Hutapea, T. W. Pribadi, and I. Baihaqi, "Perancangan Aplikasi Berbasis Android untuk Manajemen Proyek Reparasi Kapal," J. Tek. ITS, vol. 6, no. 2, pp. 158-163, 2017.

[8] K. C. Dewi, P. I. Ciptayani, and I. W. R. Wijaya, "Agile Project Management Pada Pengembangan E-Musrenbang Kelurahan Benoa
Bali,” J. Teknol. Inf. dan Ilmu Komput., vol. 5, no. 6, pp. 723-730, 2018.

[9] P. A. Guna Permana, "Scrum Method Implementation in a Software Development Project Management," Int. J. Adv. Comput. Sci. Appl., vol. 6, no. 9, pp. 198-204, 2015.

[10] I. Kurniawan and R. R. Sani, "Pemodelan SCRUM dalam Pengembangan Sistem Informasi Kesehatan pada Klinik Ar-Rokhim Sragen Kabupaten Sragen," JOINS (Journal Inf. Syst., vol. 4, no. 1, pp. 76-86, 2019.

[11] R. S. Pressman, Software Engineering: A Practitioner's Approach, 7th ed. Boston, Mass: McGraw-Hill/Higher Education, 2010.

[12] W. Gata and G. Gata, Sukses Membangun Aplikasi Penjualan dengan Java. Jakarta: Elex Media Komputindo, 2013. 